\title{
OPTIMISED MACHINING OF FIBRE REINFORCED MATERIAL
}

\author{
Berger, D.; Bleicher, F.; Dorn, C. \& Puschitz, F.
}

Abstract: Fibre reinforced materials are getting more and more important for European manufactures. Coming from automotive and aviation industry nowadays also SMEs have to deal with these high tech materials.

One of the biggest problem for such companies is the little experience they have in milling these materials. First cutting tests nearly ever result in very bad surface qualities and then companies often stop their efforts.

The focus of the cornet project HPM was to overcome these hindrances for SMEs. The biggest problem therefore is the delamination of upper and lower layer during the cutting process. The Institute for Production Engineering developed a method to reach optimised surface qualities according to the application for different types of fibre reinforced materials like Aramid and Dyneema.

Key words: aramid, dyneema, fibre reinforced material, milling
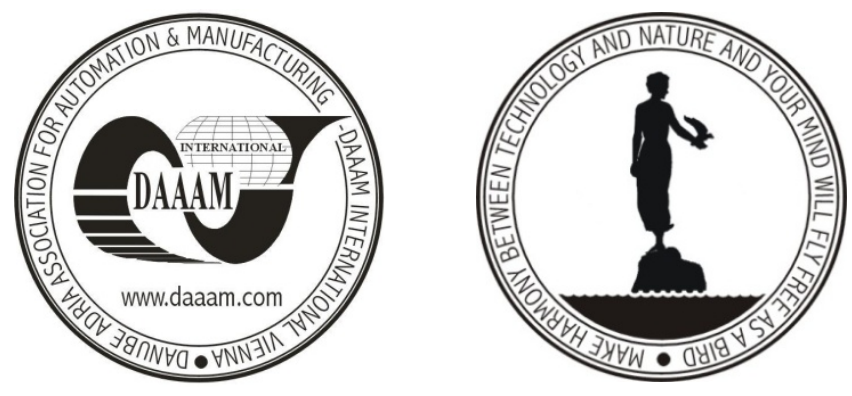

Authors' data: Dipl.-Ing. (FH). Berger, D[ominik]; Prof. Dr. Bleicher, F[riedrich]; Dipl.-Ing (FH) Dorn, C[hristoph]; Dipl.-Ing Puschitz, F[alko], Vienna University of Technology - Institute of Production Engineering, Landstr. Hauptstr. 152, 1030, Vienna, AT, TU Wien, berger@ift.at, bleicher@ift.at, dorn@ift.at, puschitz@ift.at

This Publication has to be referred as: Berger, D[ominik]; Bleicher, F[riedrich]; Dorn, C[hristoph] \& Puschitz, F[alko] (2008). Optimised Machining of Fibre Reinforced Material, Chapter 03 in DAAAM International Scientific Book 2008, pp. 027-034, B. Katalinic (Ed.), Published by DAAAM International, ISBN 978-3-901509-66-7, ISSN 1726-9687, Vienna, Austria

DOI: $10.2507 /$ daaam.scibook.2008.03 